\title{
Absolute Configuration and Antitumor Activity of Myxochelin A Produced by Nonomuraea pusilla TP-A0861 ${ }^{\dagger}$
}

\author{
Satoshi Miyanaga, Takamasa Obata, Hiroyasu Onaka, Tsuyoshi Fujita, Noriko Saito, \\ Hiroaki Sakurai, Ikuo Saiki, Tamotsu Furumai, Yasuhiro Igarashi
}

Dedicated to the late Prof. Kenneth Rinehart

Received: September 4, 2006 / Accepted: October 31, 2006

(C) Japan Antibiotics Research Association

\begin{abstract}
In the screening of antitumor compounds from microbial secondary metabolites, myxochelin A was isolated from a culture broth of Nonomuraea pusilla TPA0861. The absolute configuration was determined to be $S$ by synthesizing both enantiomers from an L- or D-lysine derivative and comparing their specific rotations. Both enantiomers of myxochelin A showed remarkable inhibitory effects on the invasion of murine colon 26-L5 carcinoma cells at non-cytotoxic concentrations.
\end{abstract}

Keywords myxochelin A, invasion, antitumor, Nonomuraea

\section{Introduction}

Tumor invasion is the major cause of treatment failure and death in cancer patients. The process of invasion into the basement membrane is a cascade of sequential complex steps, mainly consisting of tumor cell adhesion, enzymatic degradation of extracellular matrix proteins, and migration [1]. Compounds that inhibit any of these steps are expected to be candidates of anti-metastatic and/or anti-invasive agents. Hence, the clinical efficacy of such invasive inhibitors in cancer chemotherapy are extensively exploited $[2,3]$.

In the screening for anti-invasive compounds from natural products, myxochelin A (1) was found to inhibit the in vitro tumor cell invasion. Herein, we describe the isolation, structure determination, synthesis and biological properties of $\mathbf{1}$.

\section{Results and Discussion}

\section{Screening and Structure Determination}

The screening method employed in this study is based on the experimental model of tumor cell invasion using Transwell cell culture chamber and Matrigel, the reconstituted basement membrane [4]. This bioassay enables the detection of compounds that inhibit cell adhesion, enzymatic degradation of extracellular matrix, or migration. While screening for anti-invasive compounds from our natural products library, significant activity was shown by myxochelin A (1, Fig. 1) isolated from the culture broth of the actinomycete Nonomuraea pusilla TP-
Y. Igarashi (Corresponding author), S. Miyanaga, T. Obata, H. Onaka, T. Furumai: Department of Engineering, Toyama Prefectural University, 5180 Kurokawa, Imizu, Toyama 939-0398, Japan, E-mail: yas@pu-toyama.ac.jp

T. Fujita: Suntory Institute for Bioorganic Research, 1-1-1 Wakayamadai, Shimamoto, Mishima, Osaka 618-8503, Japan

N. Saito: National Institute of Infectious Diseases, 1-23-1 Toyama, Shinjuku, Tokyo 162-8640, Japan
H. Sakurai, I. Saiki: Department of Bioscience, Institute of Natural Medicine, Toyama University, 2630 Sugitani, Toyama 930-0194, Japan

† Bioactive microbial metabolites Part 30. Part 29: Y. Igarashi, S. Miura, T. Fujita, T. Furumai. Pterocidin, a cytotoxic compound from the endophytic Streptomyces hygroscopicus. J Antibiot 59: 193-195 (2006) 
A0861 (Fig. 2). Although 1 is found from myxobacterial strains such as Angiococcus [5] and Stigmatella [6], this is the first example of isolation of $\mathbf{1}$ from actinomycetes. In the original paper reported by Kunze et al. [5], there is no description of specific rotation and absolute configuration, and to our knowledge no report on the absolute structure exists after the first publication. Inconsistently, the $R$ configuration is indicated for $\mathbf{1}$ in the Dictionary of Natural Products although no literatures are cited for the determination of the absolute configuration. Therefore, we decided to determine the absolute configuration through chemical synthesis.

The synthetic scheme for $(S)$-myxochelin A (1) is shown in Fig. 3. The synthesis was started with $t$-Boc-protected lysine $(S)$-2. The carboxyl group of $(S)-\mathbf{2}$ was reduced by the treatment of its mixed anhydride with sodium borohydride [7] to give the alcohol (S)-3. After removal of the Boc groups by acidic treatment, two amino groups of $(S)-\mathbf{4}$ were acylated with the benzylated 2,3dihydroxybenzoic acid [8] using BOP reagent [9] to give compound $(S)-\mathbf{5}$. The benzyl groups of $(S)-\mathbf{5}$ were removed by hydrogenolysis to afford $(S)$-1 with $[\alpha]_{\mathrm{D}}^{24}-16.9$ (c $0.088, \mathrm{MeOH})$. Starting with the enantiomer $(R)-2$ the same sequence of reactions delivered $(R)-1$ with $[\alpha]_{\mathrm{D}}^{25}+18.3(c$ $0.25, \mathrm{MeOH})$. Natural 1 produced by the actinomycete strain TP-A0861 had $[\alpha]_{\mathrm{D}}^{21}-16.5(c \quad 0.85, \mathrm{MeOH})$ and hence the absolute configuration was determined to be $S$.<smiles>O=C(NCCCC[C@H](CO)NC(=O)c1cccc(O)c1O)c1cccc(O)c1O</smiles>

Fig. 1 Structure of (S)-(-)-myxochelin A (1).

\section{Bioactivity}

The cytotoxic effects of $(R)$ - and $(S)$-myxochelin A (1) on murine colon 26-L5 cells were assessed at the concentrations from 0.1 to $3.0 \mu \mathrm{g} / \mathrm{ml}$. Both compounds showed no cytotoxicity against 26-L5 cells at concentrations of $1.0 \mu \mathrm{g} / \mathrm{ml}$ and less. A weak cytotoxic effect (20 30\% growth inhibition) was observed at the concentration of $3.0 \mu \mathrm{g} / \mathrm{ml}$ (Fig. $4 \mathrm{a}$ ). We next examined the anti-invasive property of $(R)$ - and $(S)-1$ at non-cytotoxic concentrations. Both enantiomers inhibited the in vitro invasion of colon 26-L5 cells dose-dependently (Figs. 4b and $4 \mathrm{c})$. Compared to the natural enantiomer $(S)-\mathbf{1},(R)-\mathbf{1}$ was slightly less potent but almost comparable, suggestive of the importance of 2,3-dihydroxybenzoyl moiety and the insignificance of the side-chain stereochemistry in the antiinvasive activity. Furthermore, the effect of $(S)$-1 on tumor cell migration toward an extracellular matrix protein (fibronectin) was examined to obtain an insight into the inhibition mechanism. The migration of colon 26-L5 cells was not inhibited by $(S)-\mathbf{1}$ (Fig. 4d), indicating that $(S)-\mathbf{1}$ may act on the molecule(s) related to cell adhesion or

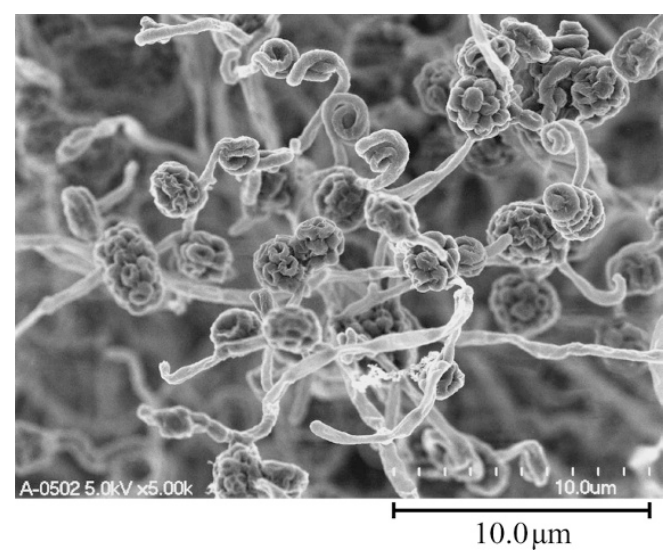

Fig. 2 Scanning electron micrograph of Nonomuraea pusilla TP-A0861.

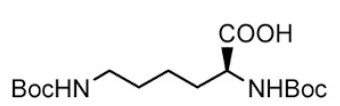

$(S)-2$

1) BOP reagent

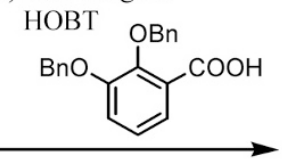

2) $\mathrm{H}_{2}, \mathrm{Pd} / \mathrm{C}$
1) $\mathrm{ClCOOEt}$

2) $\mathrm{NaBH}_{4}, \mathrm{MeOH}$

3) $1 \mathrm{~N} \mathrm{HCl}$<smiles>[R]NCCCC[C@@H](CO)N[R]</smiles>

(S)-3: $\mathrm{R}=t$-Boc

$(S)-4: \mathrm{R}=\mathrm{H}$<smiles>[R]Oc1cccc(C(=O)NCCCC[C@H](CO)NC(=O)c2cccc([R2])c2[R])c1[R]</smiles>

$(S)-\mathbf{5}: \mathrm{R}=\mathrm{Bn}$

(S)-Myxochelin A (1): $\mathrm{R}=\mathrm{H}$

Fig. 3 Synthesis of (S)-myxochelin A. 
(a)

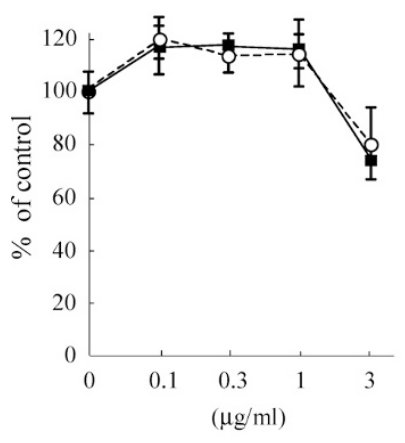

(b)

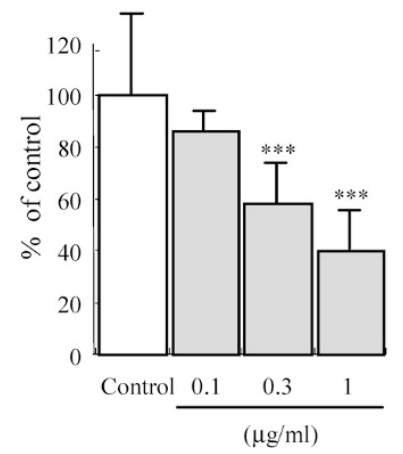

(c)

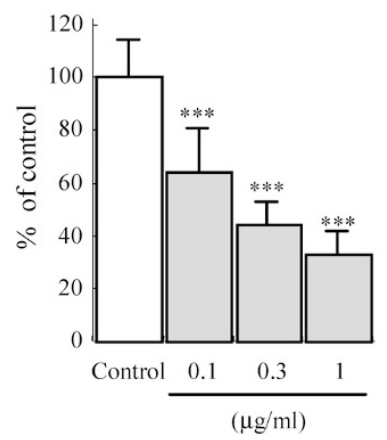

(d)

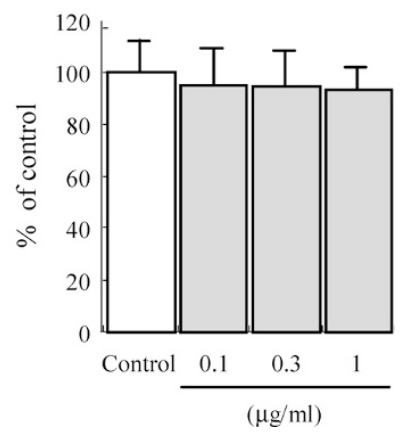

Fig. 4 Biological activities of myxochelin A (1).

(a) Cytotoxic acitivity of (R)-1 (squares) and (S)-1 (circles) against murine colon 26-L5 cells. (b) Inhibition of tumor cell invasion by (R)-1. (c) Inhibition of tumor cell invasion by (S)-1. (d) Inhibitory effect of (S)-1 on tumor cell migration. The data are expressed as the mean \pm S.D. *** $p<0.001$ as compared with the control by Student's two-tailed $t$-test.

extracellular matrix degradation.

Myxochelin A (1) has been reported to show antibacterial [5] and antioxidative [10] activities, and these activities are attributed to catecholate (2,3dihydroxybenzoate) moiety. There are a number of microbial secondary metabolites containing the catecholate group(s), and many of them are classified as siderophores which function in the producing microorganism to acquire ferric ions from the environment. In addition to the ironchelating activity, some of the catecholate-containing metabolites are reported to have antiviral, antibacterial, and cytotoxic activities [11, 12]. However, the anti-invasive activity of this class of compounds has not been reported.

In our present study, myxochelin A (1) was found to inhibit in vitro tumor cell invasion at relatively low concentrations without any cytotoxic acitivty. This finding suggests that $\mathbf{1}$ can be a lead molecule for anticancer drug development. Further study of the mode of action and structure-activity relationships is currently in progress.

\section{Experimental}

\section{Instrumental Analysis}

NMR spectra were recorded on a JEOL JMN-LA400 operating at $400 \mathrm{MHz}\left({ }^{1} \mathrm{H}\right)$ and $100 \mathrm{MHz}\left({ }^{13} \mathrm{C}\right)$. Chemical shifts are referenced to solvent, e.g., $\mathrm{CDCl}_{3}\left(\delta_{\mathrm{H}}\right.$ observed at $7.26 \mathrm{ppm}$ and $\delta_{\mathrm{C}}$ observed at $\left.77.0 \mathrm{ppm}\right), \mathrm{CD}_{3} \mathrm{OD}\left(\delta_{\mathrm{H}}\right.$ observed at $3.31 \mathrm{ppm}$ and $\delta_{\mathrm{C}}$ observed at $49.0 \mathrm{ppm}$ ), or DMSO- $d_{6}\left(\delta_{\mathrm{H}}\right.$ observed at $2.50 \mathrm{ppm}$ and $\delta_{\mathrm{C}}$ observed at $39.5 \mathrm{ppm}$ ). IR spectra were collected on a Shimadzu FTIR300. Specific rotations were measured on a Jasco DIP1030. HR-FABMS were measured using a JEOL JMS-
HX110A.

\section{Taxonomy of the Producing Strain}

Actinomycete strain TP-A0861 was isolated from the root of a soybean collected in Toyama, Japan, according to the procedure previously reported [13]. In brief, the collected plant was washed with tap water and dried for 2 days at room temperature. The plant was cut into 3 - to 5 -cm pieces. The pieces were surface-sterilized with $1 \% \mathrm{NaClO}$ for 2 minutes, rinsed with sterilized water, soaked in $70 \%$ ethanol for 2 minutes, and dried for 1 hour under UV light in a clean-bench. Then the pieces were placed on an agar plate composed of $1.5 \%$ agar containing amphotericin B $0.005 \%$, benomyl $0.02 \%$, and cycloheximide $0.005 \%$. The plate was incubated for 30 days at $32^{\circ} \mathrm{C}$, and the actinomycete colony growing on a plant piece was collected. The pure culture was maintained on Bn-2 agar medium at $20^{\circ} \mathrm{C}$.

The spore chain of strain TP-A0861 forms a compact spiral and seems to be a pseudo-sporangium (Fig. 2). Each chain has more than ten spores with smooth surfaces. The aerial mass color shows white and the color of reverse side brown to yellow. Diffusible pigments are not formed. The strain can utilize inositol, arabinose, rhamnose and raffinose for growth. The whole-cell hydrolysate contains meso-diaminopimelic acid, glucose, ribose, mannose and madurose. Due to its morphological features as well as $16 \mathrm{~S}$ rDNA sequence $(99.52 \%$ similarity to Nonomuraea pusilla), the strain can be assigned to Nonomuraea pusilla.

\section{Fermentation and Isolation}

Seed and production fermentation of strain TP-A0861 were carried out in V-22 and A-3M medium, respectively, as 
described previously [14]. Media compositions are as follows: V-22: soluble starch $1 \%$, glucose $0.5 \%$, NZ-case $0.3 \%$, yeast extract $0.2 \%$, tryptone $0.1 \%, \mathrm{~K}_{2} \mathrm{HPO}_{4} 0.1 \%$, $\mathrm{MgSO}_{4} \cdot 7 \mathrm{H}_{2} \mathrm{O} 0.05 \%, \mathrm{CaCO}_{3} 0.3 \%(\mathrm{pH}$ 7) and $\mathrm{A}-3 \mathrm{M}$ : soluble starch $2 \%$, glucose $0.5 \%$, glycerol $2 \%$, Pharmamedia $1.5 \%$, yeast extract $0.3 \%$, Diaion HP-20 1\% (pH 7).

The whole culture broth (4 liters) was extracted with 1butanol (2 liters) and the organic layer was concentrated in vacuo to give a crude extract $(15 \mathrm{~g})$. The extract was chromatographed on a silica gel column with $\mathrm{CHCl}_{3}$ $\mathrm{MeOH}(20: 1 \sim 0: 1)$. The active fractions $(4: 1 \sim 0: 1)$ were collected and evaporated to give a crude material. It was further purified by ODS column chromatography with $\mathrm{CH}_{3} \mathrm{CN}-0.15 \% \quad \mathrm{KH}_{2} \mathrm{PO}_{4} \quad(\mathrm{pH} \quad 3.5) \quad(20: 80 \sim 80: 20)$. Fractions containing myxochelin A $(20: 80 \sim 40: 60)$ were concentrated to an aqueous solution that was extracted with 1-butanol. The butanol solution was concentrated to a brown solid (1.2 g). This was further purified by preparative HPLC (Cosmosil 5C18-AR-II, $250 \times 20 \mathrm{~mm}$ i.d., $40 \%$ $\mathrm{MeOH}$ in distilled water), and the collected fraction was concentrated to give myxochelin A $(\mathbf{1}, 102 \mathrm{mg})$ : colorless amorphous; $[\alpha]_{\mathrm{D}}^{25}-16.5(c 0.85, \mathrm{MeOH}) ;{ }^{1} \mathrm{H}$ NMR and ${ }^{13} \mathrm{C}$ NMR data are listed in Table 1; HR-FABMS $m / z 405.1663$ $[\mathrm{M}+\mathrm{H}]^{+}$, calcd 405.1662 (for $\mathrm{C}_{20} \mathrm{H}_{25} \mathrm{~N}_{2} \mathrm{O}_{7}$ ).

\section{(S)-2,6-Bis(tert-butoxycarbonyl)amino-1-hexanol (3)}

To a stirred solution of $N-\alpha-N-\varepsilon$-bis-(tert-butoxycarbonyl)L-lysine $(2,0.403 \mathrm{~g}, 1.08 \mathrm{mmol})$ and $\mathrm{Et}_{3} \mathrm{~N}(0.11 \mathrm{ml}$, $1.08 \mathrm{mmol})$ in THF $(3.0 \mathrm{ml})$ was added ethyl chloroformate $(0.12 \mathrm{ml}, 1.08 \mathrm{mmol})$ at $-5 \sim-10^{\circ} \mathrm{C}$ over 5 minutes. After stirring for 30 minutes at the same temperature, the reaction mixture was filtered on Celite. To the filtrate was added $\mathrm{NaBH}_{4}(0.129 \mathrm{~g}, 3.40 \mathrm{mmol})$ in one portion and $\mathrm{MeOH}(0.68 \mathrm{ml})$ dropwise at $10^{\circ} \mathrm{C}$ over 1 hour. The reaction mixture was quenched with $1 \mathrm{~N} \mathrm{HCl}(7 \mathrm{ml})$ and extracted with EtOAc. The organic layer was dried over anhydrous $\mathrm{Na}_{2} \mathrm{SO}_{4}$, filtered, and concentrated in vacuo to give $(S)$-3 $(0.217 \mathrm{~g}, 60.5 \%)$. (S)-3: ${ }^{1} \mathrm{H}$ NMR $\left(\mathrm{CDCl}_{3}\right) \delta$ $1.11 \sim 1.35(24 \mathrm{H}), 2.86(2 \mathrm{H}, \mathrm{m}), 3.34(3 \mathrm{H}, \mathrm{m}), 5.04(1 \mathrm{H}$, br.s), 5.09 (1H, br.s).

\section{(S)-2,6-Diamino-1-hexanol (4)}

(S)-3 (197 mg, $0.593 \mathrm{mmol})$ was dissolved in $1 \mathrm{~N} \mathrm{HCl}$ $(10 \mathrm{ml})$. After stirring for 18 hours at room temperature, the reaction mixture was concentrated in vacuo to give the $\mathrm{HCl}$ salt of $(S)-4$ (126 mg, quant.). This was employed in the next reaction without further purification. $(S)-4:{ }^{1} \mathrm{H}$ NMR $\left(\mathrm{CD}_{3} \mathrm{OD}\right) \delta 1.46 \sim 1.54(2 \mathrm{H}, \mathrm{m}), 1.62 \sim 1.75(4 \mathrm{H}, \mathrm{m}), 2.95$ $(2 \mathrm{H}, \mathrm{t}, J=8.0 \mathrm{~Hz}), 3.22(1 \mathrm{H}, \mathrm{m}), 3.57(1 \mathrm{H}, \mathrm{dd}, J=6.6$ and $11.7 \mathrm{~Hz}), 3.76(1 \mathrm{H}, \mathrm{dd}, J=3.6$ and $11.7 \mathrm{~Hz})$.
Table 1 NMR data of myxochelin A

\begin{tabular}{|c|c|c|c|}
\hline No. & $\delta_{\mathrm{H}}(\mathrm{J} \mathrm{Hz})^{a}$ & $\delta_{\mathrm{C}}{ }^{b}$ & $\mathrm{HMBC}$ \\
\hline \multirow[t]{2}{*}{1} & $3.47 \mathrm{dd}(5.9,10.8)$ & 63.1 & 2,3 \\
\hline & $3.43 \mathrm{dd}(5.9,10.8)$ & & \\
\hline 2 & $4.00 \mathrm{~m}$ & 51.2 & \\
\hline 3 & $1.54 \mathrm{~m}$ & 30.1 & 2,4 \\
\hline 4 & $1.34 \mathrm{~m}$ & 23.2 & $2,3,5,6$ \\
\hline 5 & $1.55 \mathrm{~m}$ & 28.8 & 6 \\
\hline 6 & $3.27 \mathrm{~m}$ & 48.6 & $4,5,7^{\prime \prime}$ \\
\hline $1^{\prime}$ & & 115.3 & \\
\hline $2^{\prime}$ & & 149.5 & \\
\hline $3^{\prime}$ & & $146.1^{c}$ & \\
\hline $4^{\prime}$ & $6.91 \mathrm{~d}(7.8)$ & 118.7 & $2^{\prime}, 3^{\prime}, 6^{\prime}$ \\
\hline $5^{\prime}$ & 6.68 t (7.8) & $117.8^{d}$ & $1^{\prime}, 3^{\prime}$ \\
\hline $6^{\prime}$ & $7.36 \mathrm{~d}(8.0)$ & 117.5 & $1^{\prime}, 2^{\prime}, 4^{\prime}, 7^{\prime}$ \\
\hline $7^{\prime}$ & & 169.5 & \\
\hline $1^{\prime \prime}$ & & 114.9 & \\
\hline $2^{\prime \prime}$ & & 149.7 & \\
\hline $3^{\prime \prime}$ & & $146.2^{c}$ & \\
\hline $4^{\prime \prime}$ & $6.90 \mathrm{~d}(7.8)$ & 118.7 & $2^{\prime \prime}, 3^{\prime \prime}, 6^{\prime \prime}$ \\
\hline $5^{\prime \prime}$ & 6.66 t (7.8) & $117.7^{d}$ & $1^{\prime \prime}, 3^{\prime \prime}$ \\
\hline $6^{\prime \prime}$ & $7.26 \mathrm{~d}(8.0)$ & 117.1 & $1^{\prime \prime}, 2^{\prime \prime}, 4^{\prime \prime}, 7^{\prime \prime}$ \\
\hline $7^{\prime \prime}$ & & 169.7 & \\
\hline $2-\mathrm{NH}$ & $8.31 \mathrm{~d}(8.3)$ & & $2,7^{\prime}$ \\
\hline 6-NH & $8.72 \mathrm{t}(5.6)$ & & $6,7^{\prime \prime}$ \\
\hline
\end{tabular}

${ }^{a}$ Recorded at $400 \mathrm{MHz}$ in DMSO- $d_{6} \cdot{ }^{b}$ Recorded at $100 \mathrm{MHz}$ in DMSO- $d_{6}$. ${ }^{c, d}$ Assignments interchangeable.

\section{(S)-2,6-Bis[(2,3-dibenzyloxybenzoyl)amino]-1-hexanol}

(5)

To a mixture of $(S)-4(49.8 \mathrm{mg}, 0.38 \mathrm{mmol})$, BOP reagent (464 mg, $1.05 \mathrm{mmol})$ and 1-hydroxybenzotriazole (143 mg, $1.05 \mathrm{mmol})$ in dry DMF $(3 \mathrm{ml})$ were added 2,3dibenzyloxybenzoic acid (267 $\mathrm{mg}, 0.80 \mathrm{mmol})$ and $i$ - $\mathrm{Pr}_{2} \mathrm{NEt}$ $(0.313 \mathrm{ml}, 0.90 \mathrm{mmol})$. After stirring for 18 hours at room temperature, the reaction mixture was poured into ice-water and extracted with EtOAc. The organic layer was subsequently washed with $0.5 \mathrm{~N} \mathrm{HCl}$, saturated $\mathrm{NaHCO}_{3}$ solution and brine, dried over anhydrous $\mathrm{MgSO}_{4}$, filtered and concentrated in vacuo. The residue was purified on a silica gel column (hexane $-\mathrm{EtOAc}=10: 1 \sim 1: 3$ ) to give (S)-5 (113 mg, 39.2\% yield) as colorless amorphous. (S)-5: $[\alpha]_{\mathrm{D}}^{22}-26.9(c 1.0, \mathrm{MeOH})$; IR $v_{\max }(\mathrm{KBr}) \mathrm{cm}^{-1} 3360$, 2940, 1660, 1570; ${ }^{1} \mathrm{H}$ NMR $\left(\mathrm{CDCl}_{3}\right) \delta 1.08 \sim 1.40(6 \mathrm{H}, \mathrm{m})$, $3.13(1 \mathrm{H}, \mathrm{m}), 3.20(1 \mathrm{H}, \mathrm{m}), 3.42(1 \mathrm{H}, \mathrm{dd}, J=5.8$ and $11.0 \mathrm{~Hz}), 3.52(1 \mathrm{H}$, br.d, $J=11.0 \mathrm{~Hz}), 3.94(1 \mathrm{H}, \mathrm{m}), 5.04$ $(2 \mathrm{H}, \mathrm{s}), 5.05(1 \mathrm{H}, \mathrm{d}, J=10.7 \mathrm{~Hz}), 5.11(2 \mathrm{H}, \mathrm{s}), 5.12(2 \mathrm{H}, \mathrm{s})$, $5.14(1 \mathrm{H}, \mathrm{d}, J=10.7 \mathrm{~Hz}), 7.08 \sim 7.12(4 \mathrm{H}, \mathrm{m}), 7.27 \sim 7.69$ $(20 \mathrm{H}, \mathrm{m}), 7.69 \sim 7.72(2 \mathrm{H}, \mathrm{m}), 7.91(1 \mathrm{H}, \mathrm{t}, J=5.6 \mathrm{~Hz}), 8.12$ 
$(1 \mathrm{H}, \mathrm{d}, J=7.8 \mathrm{~Hz}) ;{ }^{13} \mathrm{C} \mathrm{NMR}\left(\mathrm{CD}_{3} \mathrm{OD}\right) \delta 23.0,29.0,30.1$, 39.0, 52.1, 65.4, 71.1, 71.2, 76.1, 76.2, 116.8, 117.0, 123.1, $123.2,124.2,124.3,126.8,127.2,127.5,127.6,128.13$, $128.15,128.5,128.57,128.58,128.6,136.23,136.24$, $136.3,146.6,146.8,151.5,151.6,165.0,165.8$; HRFABMS found $m / z 765.3542[\mathrm{M}+\mathrm{H}]^{+}$, calcd $m / z 765.3540$ (for $\mathrm{C}_{48} \mathrm{H}_{49} \mathrm{~N}_{2} \mathrm{O}_{7}$ ).

\section{(S)-Myxochelin A (1)}

A mixture of $(S)-5(20 \mathrm{mg}, 0.026 \mathrm{mmol})$ and $10 \% \mathrm{Pd} / \mathrm{C}$ $(10 \mathrm{mg})$ in $\mathrm{MeOH}(5 \mathrm{ml})$ was stirred under $\mathrm{H}_{2}$ at room temperature. After 2.5 hours, the mixture was filtered through Celite, and the filtrate was concentrated in vacuo. The residue was purified by preparative HPLC under the same conditions described for the natural myxochelin A to afford $(S)-1$ (11 mg, quant.): $[\alpha]_{\mathrm{D}}^{24}-16.9$ (c 0.088, MeOH); HR-FABMS $m / z 405.1660[\mathrm{M}+\mathrm{H}]^{+}$, calcd 405.1662 (for $\mathrm{C}_{20} \mathrm{H}_{25} \mathrm{~N}_{2} \mathrm{O}_{7}$ ).

\section{(R)-Myxochelin A [(R)-1]}

$(R)$-Myxochelin A was synthesized in the same manner as described above, starting from $N$ - $\alpha$ - $N$ - $\varepsilon$-bis-(tertbutoxycarbonyl)-D-lysine. $(R)-\mathbf{1}:[\alpha]_{\mathrm{D}}^{25}+18.3$ (c 0.25 , $\mathrm{MeOH})$; HR-FABMS $m / z \quad 405.1658[\mathrm{M}+\mathrm{H}]^{+}$, calcd 405.1662 (for $\mathrm{C}_{20} \mathrm{H}_{25} \mathrm{~N}_{2} \mathrm{O}_{7}$ ).

\section{Cytotoxicity Assay}

Murine colon 26-L5 carcinoma cells $\left(5 \times 10^{3}\right)$ were suspended in $100 \mu \mathrm{l}$ of RPMI containing $1 \%$ FCS and various concentrations of $(R)$ - or $(S)-\mathbf{1}$, and seeded into the wells of a 96-well culture plate. After 24 hours of incubation in a humidified $5 \% \mathrm{CO}_{2}$ incubator at $37^{\circ} \mathrm{C}$, the wells were washed with PBS and the cells were fixed with $20 \%$ formalin. Then, the wells were washed with PBS, and the cells were stained with crystal violet for 30 minutes. After washing with PBS, the crystal violet dye was extracted with $30 \%$ acetic acid and the absorbance at $590 \mathrm{~nm}$ was measured.

\section{In Vitro Invasion and Migration Assays}

Invasion of tumor cells through the reconstituted basement membrane, Matrigel, was assessed in Transwell cell culture chambers [4]. In brief, polyvinylpyrrolidone-free carbonate filters of $8.0-\mu \mathrm{m}$ pore size (Nucleopore, Pleasanton, CA, USA) were mounted in the Transwell chambers (Costar 3422, Cambridge, MA, USA). The lower surface of the filters was coated with $20 \mu \mathrm{g}$ of fibronectin and the upper surface was coated with $5 \mu \mathrm{g}$ of Matrigel (Collaborative Research Inc., Bedford, MA, USA). Exponentially growing colon 26-L5 cells were harvested and resuspended in RPMI containing $1 \% \mathrm{FCS}$ and various concentrations of $(R)$ - or $(S)-1$. One hundred $\mu$ l of cell suspension $\left(2 \times 10^{4}\right.$ cells/chamber) was then added to the upper chamber and incubated in a 24 -well culture plate at $37^{\circ} \mathrm{C}$ for $6 \sim 8$ hours. At the end of incubation, the cells on the filters were fixed with methanol and stained with hematoxylin for 3 minutes and eosin for 10 seconds. After gentle rinsing with water, the cells remaining in the Matrigel were removed by wiping the upper chamber with a cotton swab. The filters containing the stained cells that had invaded or migrated through the lower surface were removed from the Transwell chambers. The number of the invaded or migrated cells was counted in five different fields of each well under the microscope.

The migration assay was performed using a procedure similar to that of the invasion assay except the upper surface of the filters was not coated with Matrigel.

\section{References}

1. Kohn EC, Liotta LA. Molecular insights into cancer invasion: strategies for prevention and intervention. Cancer Res 51: 1856-1862 (1995)

2. Latreille J, Batist G, Laberge F, Champagne P, Croteau D, Falardeau P, Levinton C, Hariton C, Evans WK, Dupont E. Phase I/II trial of the safety and efficacy of AE-941 (Neovastat) in the treatment of non-small-cell lung cancer. Clin Lung Cancer 4: 231-236 (2003)

3. Rosenbaum E, Zahurak M, Sinibaldi V, Carducci MA, Pili R, Laufer M, DeWeese TL, Eisenberger MA. Marimastat in the treatment of patients with biochemically relapsed prostate cancer: a prospective randomized, double-blind, phase I/II trial. Clin Cancer Res 11: 4437-4443 (2005)

4. Saito KI, Oku T, Ata N, Miyashiro H, Hattori M, Saiki I. A modified and convenient method for assessing tumor cell invasion and migration and its application to screening for inhibitors. Biol Pharm Bull 20: 345-348 (1997)

5. Kunze B, Bedorf N, Kohl W, Höfle G, Reichenbach H. Myxochelin A, a new iron-chelating compound from Angiococcus disciformis (Myxobacterales). Production, isolation, physico-chemical and biological properties. J Antibiot 42: 14-17 (1989)

6. Silakowski B, Kunze B, Nordsiek G, Blocker H, Höfle G, Muller R. The myxochelin ion transport regulon of the myxobacerium Stigmatella aurantiaca Sg a15. Eur J Biochem 267: 6476-6485 (2000)

7. Soai K, Yokoyama S, Mochida K. Reduction of symmetric and mixed anhydrides of carboxylic acids by sodium borohydride with dropwise addition of methanol. Synthesis 647-648 (1987)

8. Kanai F, Isshiki K, Umezawa Y, Morishima H, Naganawa H, Takita T, Takeuchi T, Umezawa H. Vanoxonin, a new inhibitor of thymidylate synthetase. II. Structure 
determination and total syntheses. J Antibiot 38: 31-38 (1985)

9. Castro B, Dormoy JR, Dourtoglou B, Evin G, Selve C, Ziegler JC. Peptide coupling reagents VI. A novel, cheaper preparation of benzotrizaolyloxytris[dimethylamino] phosphonium hexafluorophosphate (BOP reagent). Synthesis 751-752 (1976)

10. Lee HH, Ahn JW, Lee J, Kim YC, Chung SK, Kwon JH. Antioxidative and free radical scavenging activities of myxochelin A isolated from Angiococcus sp. (Myxobacteria). Food Sci Biotech 11: 184-187 (2002)

11. Bergeron RJ, Cavanaugh PF Jr, Kline SJ, Hughes RG Jr, Elliott GT, Porter CW. Antineoplastic and antiherpetic activity of spermidine catecholamide iron chelators.
Biochem Biophys Res Commun 121: 848-854 (1984)

12. Wells JS, Trejo WH, Principe PA, Sykes RB. Obafluorin, a novel beta-lactone produced by Pseudomonas fluorescens. Taxonomy, fermentation and biological properties. J Antibiot 37: 802-803 (1984)

13. Igarashi Y, Iida T, Sasaki T, Saito N, Yoshida R, Furumai T. Isolation of actinomycetes from live plants and evaluation of antiphytopathogenic activity of their metabolites. Actinomycetol 16: 9-13 (2002)

14. Igarashi Y, Iida T, Yoshida R, Furumai T. Pteridic acids A and $\mathrm{B}$, novel plant growth promoters with auxin-like activity from Streptomyces hygroscopicus TP-A0451. J Antibiot 55: 764-767 (2002) 